in a number of recent cases courts have granted relief against such an association of employees whether incorporated or not. ${ }^{1 \pi}$

\title{
FREEDOM OF SPEECH AND STATES' RIGHTS
}

In Gilbert v. Minnesota (1920) 4I Sup. Ct. I25, the question of freedom of speech was presented to the federal Supreme Court from a new angle. The issue was the constitutionality of a state statute making unlawful any advocacy against enlistment in the federal military or naval forces or against aiding the United States in the prosecution of war. This question is of great importance, in view of the number and drastic character of state sedition laws passed as a result of the World War, many of them after the Armistice. ${ }^{1}$ It raises primarily the issue of conflicting state and federal powers. The issue of freedom of speech was, however, directly raised, since Justice Brandeis, dissenting, ${ }^{2}$ held that freedom of speech was a "privilege or immunity" of a United States citizen within the terms of the constitutional protection, and was also a "liberty" of which a citizen cannot be deprived without due process of law. The majority did not decide the point further than to hold that Gilbert's conviction would not violate such constitutional guarantees of freedom of speech if they existed. ${ }^{3}$ The opinion

${ }^{17}$ St. Germain v. Bakery Workers' Union (rg17) 97 Wash. 282, 166 Pac. 665 ; Michael v. Hillman (I920) II2 Misc. 395,183 N. Y. Supp. I95. Where there is a strict observance of the common-law rules, however, it is necessary to sue the individuals composing the association. An excellent discussion of this question is to be found in St. Paul Typothetae v. Book-binders' Union (1905) 94 Minn. 35I, 102 N. W. 725. That a voluntary association (i. e. unincorporated) is liable for punitive damages, see Clarkson v. Laiblan (rgI9, Mo.) $216 \mathrm{~S}$. W. rozg. The court held the association liable for the wrongful acts of its officers acting within authority. For opposing view see Michaels v. Hillman (1920, Sup. Ct.) 112 Misc. 395,183 N. Y. Supp. I95.

'These are collected in Chafee, Freedom of Speech (1920) Appendix V, 399-405. For comment on the Connecticut statutes of 1919, see (19I9) 29 YALE LAw Journal, 108. The Minnesota statute in question (Laws I9I7, ch. 463) is not limited to the period of war and makes unlawful any kind of teaching against enlistment. Even this was not sufficiently drastic, and hence in rgrg (Laws IgIg ch. 93) it was strengthened and the usual maximum penalty of twenty years' imprisonment was incorporated. The latter act seems, however, to be limited to the time of war.

= The majority opinion was by Mr. Justice McKenna, Mr. Justice Holmes concurring in the result. Chief Justice White dissented on the ground that after Congress had passed the Espionage Act, there was no further room for state action. Mr. Justice Brandeis dissented for similar reasons and also for the reason stated in the text.

${ }^{3}$ Quoting inter alia from Schenck v. United States (1919) 249 U. S. 47, 39 Sup. Ct. 247. But in that case the entire court agreed that the words used must be used in such circumstances and be of such a nature as to create a clear and present danger that they will bring about the substantive evils that Congress may prevent. See (1919) 29 Yale LAw Journal, 337. This case has never been overruled. A recent application of this test to set aside a conviction under the federal Act appears in Beck v. United States (1920, C. C. A. 7 th) 268 Fed. I95 (conviction of a native born citizen, for twenty years a county judge, because at a 
betrays no small trace of war emotion."

On the issue of sovereignty it is perhaps surprising to find that a majority of a court generally so federalistic in its views ${ }^{5}$ felt that a state might constitutionally circumscribe the discussion of national problems even after Congress had legislated upon the subject. Their reasons are of interest. They considered that any other view must be based upon a theory that there is something antagonistic between citizenship in a state and citizenship in the United States. Repudiating this theory, they held that the interests of the United States are also those of a state and may be cherished and fostered by that state. Hence if a state is not satisfied with a federal sentence of twenty years against an agitator, it may add a like sentence of its own. One may admit all but the conclusion and yet doubt how this settles the question as to which sovereignty shall control the subject. Again the court suggested that the state statute might be upheld as a simple exercise of the state police power to preserve the peace. Certainly every state must and does have such power; in fact it would seem that this should be the limit of its power to restrict the discussion of national issues. But a statute making it unlawful to interfere with the enlistment of men in the military or naval service of the United States is surely more than a mere police regulation designed to quell disorder. Hence Chief Justice White would seem properly to have dissented on the ground that after Congress passed the Espionage Act-which was prior to the occa-

meeting called to reorganize the county council of defense he had made what one hostile witness thought was an economic and another a patriotic address in criticism of the calling together of the county board). See also Erhardt $v$. United States (I920, C. C. A. 7th) 268 Fed. 326, reversing a conviction for words claimed to have been spoken at a neighborhood party nearly three months before defendant's arrest.

- Gilbert, an official of the Non-Partisan League, was convicted for a speech in which he attacked the democracy of America, saying. that we had better make America safe for democracy first and asking his hearers if they had had anything to say as to who should be President or as to whether we should go into the war, and that we should have voted on conscription and were stampeded into the war to pull England's chestnuts out of the fire. Unless this does so, there was no advocacy against enlistment or against prosecution of the war. Mr. Justice McKenna says that "every word" uttered by Gilbert in denunciation of the war was false and was deliberate misrepresentation and that "he could have had no purpose other than that of which he was charged." In this connection and as bearing on Gilbert's purposes, one should bear in mind the claims made for the League that it is conducting a struggle for the agrarian interests against large financial and business interests. See criticism of the case by Professor Chafee in (I92I) 25 NEW REPUBLIC, 259. At the trial Gilbert had. denied the speaking of the words in question. (I9r8) I4I Minn. 263, I69 N. W. 790. In State v. Martin (I9I8) 142 Minn. 484169 N. W. 792 , the majority at first upheld a conviction of a defendant for approving Gilbert's speech in the course of a barber shop altercation, but on August I, I9I9, a.majority of the court decided that the issues should be submitted to a new jury.

"Witness for example its decisions as to the inapplicability of state workmen's compensation acts to injuries occurring in harbors. See (1920) 29 YALE LAW JoURNAL, 925, collecting previous notes in the JouRNAL. 
sion when Gilbert made the speech in question-no further power in this field remained in the states. So Justice Brandeis, holding that such power was exclusively in the federal government, pointed out how a state by severely repressive measures might hamper the federal prosecution of war, and quoted an official of the Department of Justice to the effect that the Minnesota policy was a cause of real embarrassment and danger to the federal government. ${ }^{6}$ Inasmuch as most of the state statutes, unlike the federal Espionage Act, are not limited to a time of war, ${ }^{7}$ it may be added that a state, under such a condition of affairs as existed from I9I5 until our entrance into the war, might easily force the hands of the federal government by stern repression of the sympathizers with one of the belligerents. ${ }^{8}$

There is, however, a suggestion, explicit in the Gilbert Case and implicit in all those in accord with it, which gives ground for a possible explanation. That suggestion is that the action of the state must be one of co-operation with the federal government. Herein may lie an opportunity for the avoidance of danger. During the recent crisis the government showed beyond the possibility. of a doubt its hostility to criticism, and state repressive statutes were plainly in co-operation with the federal policy. Under a government more amenable to public opinion Gilbert v. Minnesota need not be a precedent to hamper the execution of federal policies.

C. E. C.

DEPORTATION OF ALIEN COMMUNISTS

The Act of Congress of October 16, I918, provides that aliens who are members of, or affliated with, any organization that entertains a belief in, teaches, or advocates the overthrow by force or violence of the Government of the United States may be deported. ${ }^{1}$ This statute

\footnotetext{
- John Lord O'Brian, Civil .Liberty in War-Time (1919) 42 N. Y. State Bar Asso. Rep. 275, 296.

'See note I, supra.

${ }^{8}$ Decisions of inferior tribunals on this subject seem for the most part in accord with the principal case. See State $v$. Holm (1918) 139 Minn. 267, 166 N. W. I8r, L. R. A. 1918 C, 304, with note giving the few analogous precedents prior to the war. A fairly complete picture is given by the majority and minority opinions in State v. Tachin (19rg, Sup. Ct.) 92 N. J. L. 269 , 106 Atl. I45, (1919) 93 N. J. L. 485 , I08 Atl. 318. See also State v. Gibson (I9I9, Iowa) 174 N. W. 34. Contra, Ex parte Meckel (1920, Tex. Cr. App.) 220 S. W. 81. In Ex parte Starr (r920, D. Mont.) 263 Fed. 145, the Montana act was upheld for the period prior to the passage of the federal Espionage Law, although Judge Bourquin strongly condemned the act. See (rg20) 29 YALE LAw Journar, 936. Mr. Justice McKenna cites the Minnesota decision upholding state bonuses to veterans. Gustavson v. Rhinow (1920) I44 Minn. 415, 175 N. W. 903. This point is not, however, beyond controversy. See (I920). 29 Yale LAw Journal, 690; (1920) 33 Harv. L. Rev. 846; (I920) I8 Mich. L. Rev. 535; (Ig20) 4 Minn. L. REv. 233: Cfr as to state soldiers' civil relief acts, Konkel v. State (rgIg) 168 Wis. 335 , I70 N. W..715; cf. also State v. Darwin (1918) I02 Wash. 402, 173 Pac. 29.

${ }^{1}$ U. S. Comp. St. Ann. Supp. 1919, sec. $4289 \mathrm{r} / 4 \mathrm{~b}$ ( $\mathrm{r}$ ) and sec. $4289 \mathrm{~T} / 4 \mathrm{~b}(2)$.
} 